\title{
Effects of skin temperature change, cold pain and muscle activity by Cold Air Application type on the induced delayed onset muscle soreness
}

\author{
Yoorim Choi ${ }^{*}$, Bongjae Jung ${ }^{* *}$, Byeongjun Hwang ${ }^{* * *}$ \\ Department of Physical Therapy, Taegu Science University of Korea*, Department of Radiological Science, International \\ University of Korea**, Department of Physical Therapy Yecheon orthopaedic clinic**

\section{지연성 근육통 유발 후 냉기 적용 방법이 피부온도의 변화, 냉각 통과 근육 기능에 미치는 효과}

\author{
최유림*, 정봉재 ${ }^{* *}$, 황병준*** \\ 대구과학대학교 물리치료과*, 한국국제대학교 방사선학과 ${ }^{* *}$, 예천정형외과 물리치료실***
}

\begin{abstract}
The purpose of this study was to after induced delayed onset muscle soreness, the purpose of this study is to present the effective way on skin temperature changes and cold pain for 14 subjects during to applied with only Cold-jet stream and Cold-jet stream with infra red. 14 healthy men and women who delayed onset muscle soreness eccentric contractions induced by exercise and then the biceps alone was applied to the Cold-jet stream. We measured the time that skin temperature fall from room temperature to $10^{\circ} \mathrm{C}$ (first period), the time rewarmed from $10^{\circ} \mathrm{C}$ to $20^{\circ} \mathrm{C}$ (second period), the time fall again to $10^{\circ} \mathrm{C}$ (third period) and the time rewarmed again to $20^{\circ} \mathrm{C}$ (fourth period). Cold-jet stream with infrared combination therapy was performed with the same method. Results of this study were 1st and 2nd experimental cooling experiments in the to fall to $10^{\circ} \mathrm{C}$ Cold-jet stream with infrared combination therapy than in the Cold-jet stream was longer $(\mathrm{p}<.05)$. At second period, It took longer in Cold-jet stream with infrared rewarmed than Cold-jet stream to rewarm $\operatorname{skin}(\mathrm{p}<.05)$. Cold-jet stream with infrared combination therapy than Cold-jet stream had less incidence of cold pain $(\mathrm{p}<.05)$. Thickness of biceps brachii were found significant difference related measurment each group was consistent In this study, Cold-jet stream with infrared combination therapy more effective than Cold-jet stream in reduced cold pain and lowering skin temperature. This work was supported by education capacity building project fund of Taegu Science University, 2012.
\end{abstract}

Key Words : Cold-jet stream, Infrared, ultrasound diagnosis, cold pain, Delayed Onset Muscle Soreness, Eccentric exercise-induced muscle damage.

\section{요 야}

본 연구는 급성염증과 비슷한 지연성 근육통이 있을 때 초기 한냉치료를 적용함에 있어 냉기에 의한 냉각통증을 최 소화하면서, 근육온도를 낮출 수 있는 방법으로 냉기단독과 냉기와 적외선 조사 병용을 적용하여 피부온도에 미치는 영향을 측정하고, 냉기와 적외선 병용치료의 효율성을 평가함과 동시에 초음파를 통한 근 두께를 바탕으로 등척성 근 
기능을 평가해보고자 하였다. 본 연구의 결과 냉기와 적외선 병용치료 시 냉기 단독치료보다 냉각통증의 빈도가 낮게 나타났으며, 냉각통증 자각 시점도 늦게 나타났다. 또한 충분한 냉기적용 후 피부온도가 재가온되는데 있어서 냉기를 2 회 적용할 때가 1 회 적용할 때 보다 더 느려지며, 냉기 단독치료보다 냉기와 적외선 광선 조사 병용치료 시 더 느려짐 을 나타내어 2 회 이상의 반복적인 냉기 적용이 냉기의 효용이 있다고 나타났다. 또한 상완이두근 두께 변화에 있어서 병용군이 대조군보다 더 크게 나타나 이 효과를 뒷받침하게 되었다. 이러한 연구결과 자료는 향후 급성염증이 있는 환자에게 한냉치료와 관련된 치료적인 자료로써 활용될 수 있을 것이라 생각되고 근골격계 초음파 진단기를 활용하여 통증에 대한 자각도를 간접적으로 표현하는 것이 구체화되어 임상에서 널리 활용될 것으로 보여진다.

중심단어 : 냉기치료, 적외선, 초음파진단, 냉각통, 지연성 근육통

\section{I. 서론}

지연성 근육통(delayed onset muscle soreness; DOMS) 은 감각을 둔하게 하고 근육에 통증을 유발하여 강직 (stiffness)이나 민감한 통증(tenderness)을 나타나게 한다. 이는 익숙하지 못한 갑작스러운 과격한 운동을 하였을 때 대략 여러 시간에서 24시간 후에 나타나며, 1 3일 사이에 최대에 이르러, 7 10일 후면 완전히 사라지게 된다 ${ }^{[1] . ~ ㄱ ㅣ ㅁ ㅈ ㅗ ㅇ ㅁ ㅏ ㄴ ~}(2000)$ 은 운동 후 72 시간 이내에 관절가동범 위의 감소, 통증, 부종, 대식세포의 증식, lysosomal 활동 성 증가 같은 증상이 급성 염증반응과 비슷하다고 하였 다 ${ }^{[2]}$. 지연성 근육통이 발생한 경우 통증을 줄여주는 방 법으로 냉치료, 마사지, 열 전기치료, 경피신경자극 또 는 초음파치료 등이 쓰이며, 약물요법으로 경구진통제, 비스테로이드성 소염제 등이 유용하게 사용된다 ${ }^{[2][3]}$.

통증의 평가는 환자가 표현하는 주관적인 방법에 의 존하게 되며 이를 객관화시키기 위한 여러 종류의 척 도법 및 질문법들이 개발, 연구되고 있다. 종류로는 단 순 서술척도(Simple Discriptive Scale : SDS), 시각 통증척 도(Visual Analog Scale : VAS), 구술적 평정척도(Verval Rating Scale : VRS), 등의 척도법과 McGill의 통증질문 법(McGill Pain questinnaire), Dallas 통증질문법(Dallas pain questionnaire)등이 있다. 최근들어 VAS(Visual Analog Scale, 시각 통증척도)란 전적으로 환자의 주관 적인 판단에 의존하는 것으로 각기 여러 형태의 척도 법들을 환자에게 적용시켜 타당도 및 신뢰도를 구한 결과 시각 통증척도(VAS)가 통증의 강도를 평가하는 가장 적절한 도구로 흔히 사용되고 있다 ${ }^{[4[5][6]}$.

적외선은 분자의 진동을 통하여 열을 방출하여 피
부 표면에 생리적 작용을 나타나게 하는 통증 치료로 널리 사용되는 치료 기구이다. 일반적으로 적외선 적 용시 피부 아래 $2 \mathrm{~cm}$ 의 깊이에서 $1.3^{\circ} \mathrm{C}$ 온도상승이 나 타나며 여러 논문에서 온도상승으로 인한 혈류변화 및 세포활동서 변화를 증명하였다 ${ }^{[7[8]}$.

한냉치료는 온열치료와 더불어 재활의학 영역에서 흔히 처방되는 물리치료의 한 방법으로, 혈류와 신경 전달 속도를 감소시키고, 초기 염증반응을 감소시켜 근골격계 외상, 근경련, 동통, 초기 관절염, 화상 등에 적용되고 있다 ${ }^{[9]}$. 최근에는 대기 중의 질소를 $-30^{\circ} \mathrm{C}$ 로 냉각시켜 환부에 적용하는 한냉치료로 냉기치료가 각 광을 받고 있다(이정권 외 1999). 냉기치료는 다른 한 냉치료가 20 30분의 시간이 소요되는 데 비해서 수 분 내에 같은 효과를 볼 수 있는 장점이 있으나, 피부 온도가 너무 떨어져 환자에게 냉각통증을 유발하게 되어 치료시간을 오래할 수 없는 단점이 있다 ${ }^{[10][11]}$.

본 연구는 급성염증과 비슷한 지연성 근육통이 있을 때 초기 한냉치료를 적용함에 있어 냉기에 의한 냉각 통증을 최소화하면서, 근육온도를 낮출 수 있는 방법 으로 냉기단독과 냉기와 적외선 조사 병용을 적용하여 피부온도에 미치는 영향을 측정하고, 냉기와 적외선 병용치료의 효율성을 평가함과 동시에 초음파 진단을 바탕으로 등척성 근기능을 평가해보고자 하였다.

\section{II. 연구대상 및 방법}

\section{1. 연구대상}

본 연구는 2012년 9월 26일부터 30일까지 대구의 T 대학에 재학 중인 20 세에서 24 세까지의 건강한 대학생 
"Journal of the Korean Society of Radiology, Volume 7, Number 1"

14 명의 남녀를 대상으로 하였으며, 실험 방법이 기재 된 유인물을 통해 실험에 대한 동의를 구한 후 연구를 시행하였다. 실험대상자는 혈관질환이나 감각소실, 근 골격계 질환, 실험기간동안 약물을 복용하지 않은 자, 실험하고자 하는 부위에 최근 개방성 상처 및 염증성 질환이 없는 자, 지난 3 개월간 정기적인 운동을 하지 않은 자, 한냉 불내성이 없는 자를 냉기군, 병용군으로 선정하였다. 냉기군은 7명으로 평균나이, 키, 몸무게는 각각 21.2 세, $169.7 \mathrm{~cm}, 64.8 \mathrm{~kg}$, 병용군 또한 7 명으로 21.1 세, $163.8 \mathrm{~cm}, 54.4 \mathrm{~kg}$ 이었다.

\section{2. 연구방법}

\section{1 한냉과민반응검사}

검사방법은 한냉수에 수건을 담근 후 꺼내어 물기 를 적당히 짜낸 다음 환자의 전완(forearm)을 가볍게 감싸준 후 15 초 후에 제거하였다. 이때 대상자가 한냉 에 대한 반응이 좋으면 한냉을 적용한 전완 부위가 분 홍색으로 변하고 좋지 않으면 변화가 없거나 약간 창 백해진다. 이와 같은 한냉과민반응검사를 통하여 좋은 반응결과가 나온 사람을 실험대상자로 선발하였다 ${ }^{[12]}$.

\section{2 지연성 근육통 유발}

비우세 손의 상완이두근 근력을 근력측정계 (Chatillon, USA)로 측정하고 최대저항 무게를 1RM으로 하여 $1 \mathrm{RM}$ 의 $70 \%$ 되는 무게의 덤벨을 가지고 원심성으 로 근수축을 하였다. 원심성 수축은 $90^{\circ}$ 굴곡상태에서 1 초간 유지하고 3 초 동안 서서히 신전하였으며, 10 회 를 1 세트로 하여 7 세트(70회)를 실시하여 각 세트마다 1 분의 휴식시간을 주고 DOMS를 유발하였다.

\section{3 연구의 셋팅}

대상자는 원심성 운동 후 24 시간 이후 시점에서 $\mathrm{VAS}$ 로 측정된 통증 점수가 4.5 이상으로 지연성 근육 통이 유발된 것을 확인하였다 ${ }^{[11]}$. 실험실 온도는 $25 \sim 27^{\circ} \mathrm{C}$ 를 유지하였으며 상완을 노출시킨 뒤 상완골 $1 / 2$ 지점에 상완이두근부에 냉기단독, 냉기와 적외선을 각각 적용하였다. 냉기단독은 1 단의 기류로 $10 \mathrm{~cm}$ 떨어 진 지점에서 적용하였고, 병용군은 냉기와 적외선을
동시에 적용하였다. 실험을 하는 동안 동시에 피부온 도도 측정하였다. 실험 시작에 앞서 상완이두근부의 피부온도를 기록 하였다. 1 차 실험은 냉기를 가하면서 피부온도가 $10^{\circ} \mathrm{C}$ 까지 감소하는데 걸리는 시간을 측정 하였고, 이 때 냉기의 적용을 멈춘후 피부의 온도가 20 ${ }^{\circ} \mathrm{C}$ 까지 자연 가온되는 시간을 측정하였다. 2차 실험 은 피부온도가 $20^{\circ} \mathrm{C}$ 에 도달하였을 때, 다시 냉기를 가 하면서 동일한 방법으로 시간을 한 번 더 측정하였다. 피부온도는 적외선 온도계(COS CT-30®, JAPAN)를 사용하였고 냉기치료는 냉기치료기(CRAis ${ }^{\circledR}$, Century Inc. KOREA)를, 적외선은 Infrared(Onehyo medical Inc, KOREA)를 사용하였다.

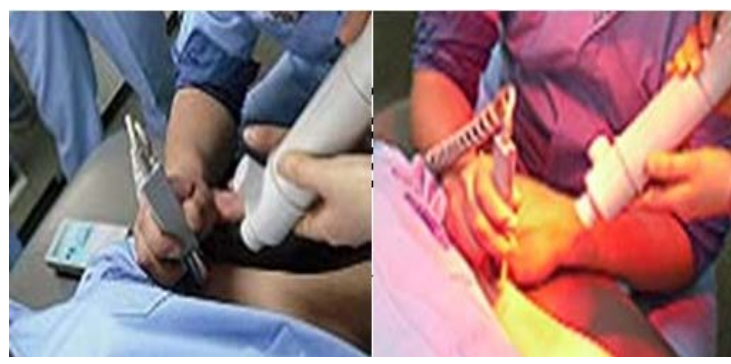

Fig. 1 Setting and Application method(Cold-jet stream group(left), Cold-jet stream + Infra red group(right)

\section{4 상완이두근 두께 초음파 측정}

상완이두근의 두께 측정을 위한 초음파 영상 수집 장치로는 estore MyLabOne을, 주파수 $10 \mathrm{MHz}(2011$, Netherlands)의 선형도자(선형 초음파 탐촉자 = 선형프 로브)를 사용하였다.

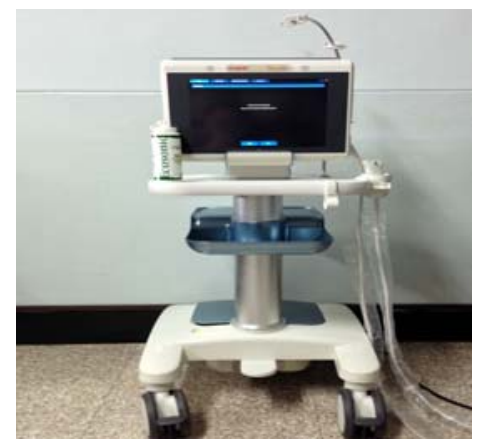

Fig. 2 ultrasound diagnosis(estore MyLabOne, Netherlands) 


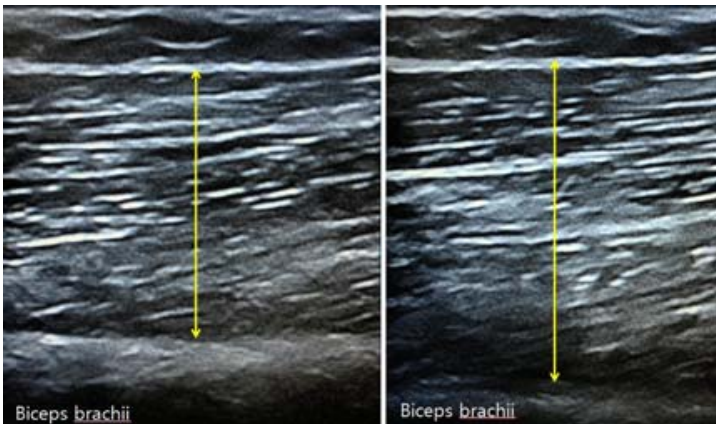

Fig. 3 Measurement of biceps brachii by ultrasound diagnosis (rest(left), isometric contraction(right))

지연성근육통을 유발하기전에 1 차 측정을 하고, 2 차 는 유발 24시간 이후 그리고 3 차는 냉기 및 적외선을 적용한 이후에 측정하였다. 환자를 편안하게 앉게 한 후 팔높이 베드에 팔을 손바닥이 위로 향하도록 뺃은 다음 원위부에 도수근력검사기의 압력판을 대고 최대 한으로 굽힘 방향으로 등척성 수축을 할때 상완이두 근의 상층막과 하층막 사이에 위치하고 있는 섬유속 (fascicle)을 확인한 후 이 각 막이 이루는 거리를 초음 파 영상에 저장한 후 caliper 프로그램을 통하여 거리를 측정하였다. 거리 측정은 이완시(휴식시)와 등척성 수 축시 각각 섬유 상측막과 하층막 거리를 측정하여 그 차이를 변화율로 환산하였다. 초음파 측정 부위는 사 전에 상완이두근에 표시하여 측정간 오차를 최소화 하였다.

\section{5 자료분석}

자료의 통계 처리를 위하여 윈도우용 SPSS version 18.0 프로그램을 이용하여 각 측정항목에 대한 평균값 과 표준오차를 산출하였고, 독립표본 T-test, 대응표본 T-test 를 사용하였고 상완이두근의 시간에 따른 변화 를 알아보기 위해 One-way repeated measure ANOVA를 실시하였다. 모든 통계의 유의수준은 $a=.05$ 로 설정하 였다.

\section{III. 결과}

\section{1. 실온에서 $10^{\circ} \mathrm{C}$ 까지 일차냉각 시 소요되는 시간}

실험 시작 전의 상완이두근부의 피부온도는 냉기군
이 $33.9^{\circ} \mathrm{C}$, 냉기와 적외선 병용군이 $33.9^{\circ} \mathrm{C}$ 로 통계적으 로 의미 있는 차이는 없었다. 냉기를 가하여 피부의 온도를 $10^{\circ} \mathrm{C}$ 까지 하강시키는 데 소요되는 시간은 병용 군이 49.0초로 냉기군 38.4초에 비해 통계적으로 유의 하게 길었다 $(\mathrm{P}<0.05)$.

\section{2. $10^{\circ} \mathrm{C}$ 에서 $20^{\circ} \mathrm{C}$ 로 일차 자연가온되는 데 소요되는 시간}

냉기군이 43.4초, 냉기와 적외선 병용군이 45.9초로 냉기군과 병용군 소요된 시간이 통계적으로 유의한 차이가 없었다 $(\mathrm{P}>0.05)$.

\section{3. $20^{\circ} \mathrm{C}$ 에서 $10^{\circ} \mathrm{C}$ 로 이차냉각 시 소요되는 시간}

냉기군이 15.1초 이고 냉기와 적외선 병용군이 19.9 초로 냉기군이 적외선 병용군에 비해 통계적으로 유 의하게 짧은 시간이 소요되었다 $(\mathrm{P}<0.05)$.

\section{4. $10^{\circ} \mathrm{C}$ 에서 $20^{\circ} \mathrm{C}$ 로 이차 자연가온되는 데 소요되는 시간}

냉기군이 52.4초, 냉기와 적외선 병용군이 58.5초로 병용군에서 자연 가온되는 데 소요되는 시간이 통계 적으로 유의하게 길었다( $\mathrm{P}<0.05)$.

\section{5. 자연가온되는데 필요한 시간 비교}

냉기군과 냉기와 적외선 병용군 모두에서 1 차 가온 되는 데 걸리는 시간보다 2 차 가온되는 데 소요되는 시간이 통계적으로 유의하게 길었다 $(\mathrm{P}<0.05)$.

\section{6. 냉각통증 자각시점}

냉기군 7명중 5명(65\%)이 냉각통증을 호소하였고 통증을 호소한 평균온도는 $11.7^{\circ} \mathrm{C}$ 였으며 평균시간은 41.5 초였다. 냉기와 적외선 병용군에서는 7 명중 3 명 $(21 \%)$ 이 냉각통증을 호소하였고 통증을 호소한 평균 온도는 $10.9^{\circ} \mathrm{C}$ 였으며, 평균시간은 52.6 초였다. 냉각통 을 느끼는 온도에는 두 그룹 모두 별 차이가 없었지만, 병용군이 냉기군에 비해 냉각통의 발생빈도가 낮았으 며 냉각통을 느끼는 시점까지의 소요시간도 유의하게 길었다 $(\mathrm{P}<0.05)$. 
Table 1. Changes in Time-Temperature occuring to cold pain after Continous Cold Jet-stream application group and Continous Cold Jet-stream with infrared application group

\begin{tabular}{|c|c|c|c|c|}
\hline \multirow{2}{*}{\multicolumn{2}{|c|}{ Sites }} & \multicolumn{2}{|c|}{ Cold Pin } & \multirow{2}{*}{$P$} \\
\hline & & A & $B$ & \\
\hline $\begin{array}{c}\text { Temeratur } \\
e\left({ }^{\circ} \mathrm{C}\right)\end{array}$ & $\begin{array}{l}\lg 1 s t \\
\text { lg } 2 s t\end{array}$ & $11.7 \pm 1.17$ & $10.9 \pm 1.61$ & 0.628 \\
\hline Time(sec) & g 1 gst & $41.5 \pm 17.1$ & $\begin{array}{c}52.6 \pm \\
7.60 \star\end{array}$ & $0.031 *$ \\
\hline \multicolumn{5}{|c|}{$\begin{array}{l}\text { Values are mean } \pm \text { standard devation } * \mathrm{p}<.05 \\
\text { A group : Cold Jet-stream application } \\
\text { B group : Cold Jet-stream wi th infrared application }\end{array}$} \\
\hline \multicolumn{5}{|c|}{$\begin{array}{l}\text { Table 2. Changes in Cold Pain time between Continous Cold } \\
\text { Jet-stream application group and Continous Cold Jet-stream } \\
\text { with infrared application group }\end{array}$} \\
\hline \multicolumn{2}{|c|}{ Group } & \multicolumn{2}{|c|}{ Average Time(Sec) } & $P$ \\
\hline \multirow{2}{*}{ Cooling 1st } & $A$ & \multicolumn{2}{|c|}{$38.48 \pm 4.09$} & \multirow{2}{*}{$0.043 *$} \\
\hline & B & $49.05 \pm$ & & \\
\hline \multirow{2}{*}{ Warming 1st } & $A$ & $43.45 \pm$ & & \multirow{2}{*}{0.563} \\
\hline & B & $45.90 \pm$ & & \\
\hline \multirow{2}{*}{ Cooling 2st } & $A$ & $15.13 \pm$ & & \multirow{2}{*}{$0.048 *$} \\
\hline & $B$ & $19.92 \pm$ & & \\
\hline \multirow{2}{*}{ Warming 2st } & $A$ & $52.45 \pm$ & & \multirow{2}{*}{$0.044 *$} \\
\hline & B & $58.51 \pm$ & & \\
\hline
\end{tabular}

Values are mean \pm standard devation $* p<.05$

Table 3. Changes in Cold Pain time Between Cold Jet-stream application group and Continous Cold Jet-stream with infrared application group in intergroup

\begin{tabular}{cccc}
\hline & Group & Average Time(Sec) & $P$ \\
\hline \hline \multirow{2}{*}{ A } & Cooling 1st - Cooling 2st & $23.35 \pm 4.97$ & $0.003 *$ \\
& Warming 1st - Warming 2st & $9.00 \pm 2.41$ & $0.010 *$ \\
\hline \multirow{3}{*}{ B } & Cooling 1st - Cooling 2st & $29.12 \pm 1.86$ & $0.001 *$ \\
& Warming 1st - Warming 2st & $12.60 \pm 1.88$ & $0.001 *$ \\
\hline
\end{tabular}

Values are mean \pm standard devation $* p<.05$

\section{7. 상완이두근 두께의 변화}

상완이두근의 이완시 두께와 등척성 수축시 두께 변화는 지연성 근육통 유발 이전에는 냉기군, 병용군 각각 $15.07 \mathrm{~mm}, 14.15 \mathrm{~mm}$ 로 비슷하게 나왔으며, 지연성 근육통 유발 이후에는 냉기군과 병용군 모두 두께 변 화가 유발전 보다는 감소하였다 $(\mathrm{P}<0.05)$. 그 이유는 지 연성 근육통 이후 발생하는 생리적 변화가 원인이었 을 것으로 보여진다. 그러나 냉기적용 이후 냉기군과 병용군은 각각 $7.09 \mathrm{~mm}, 10.62 \mathrm{~mm}$ 로 상완이두근 두께 변화가 나타났다. 냉기적용 이후 두께 변화 비율로 보 았을때 병용군이 냉기군보다 두께 변화가 더 크게 나 타나 $(\mathrm{P}<0.05)$ 근조직 속 통증변화에 냉기치료와 적외 선 병용 치료방법이 더 효과적이라고 판단된다.

Table 4. Changes of Biceps brachii thickness between Continous Cold Jet-stream application group and Continous Cold Jet-stream with infrared application group

\begin{tabular}{cccccc}
\hline \multicolumn{7}{c}{$\begin{array}{c}\text { Changes of Biceps brachii thickness } \\
\text { Site } \\
\text { rate(rest-isometric contraction)(mm) }\end{array}$} & Pre-DoMs & Post-DOMS & $\begin{array}{c}\text { Post-Applic } \\
\text { ation }\end{array}$ \\
\hline \hline A & $\begin{array}{c}15.07 \pm \\
1.53\end{array}$ & $5.99 \pm 5.60$ & $7.09 \pm 1.16$ & 5.67 & $\begin{array}{c}0.001 \\
*\end{array}$ \\
\hline B & $\begin{array}{c}14.15 \pm \\
1.50\end{array}$ & $5.40 \pm 1.58$ & $\begin{array}{c}10.62 \pm \\
11.24\end{array}$ & 4.95 & $\begin{array}{c}0.001 \\
*\end{array}$ \\
\hline
\end{tabular}

Values are mean \pm standard devation $* p<.05$

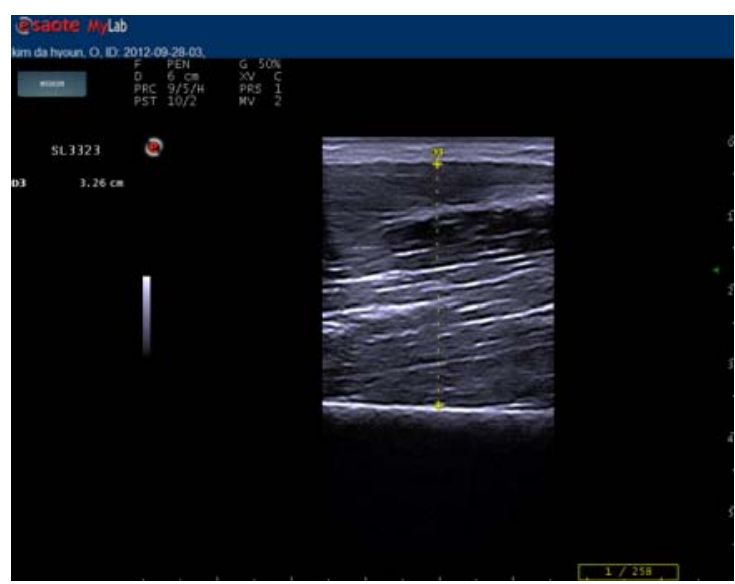




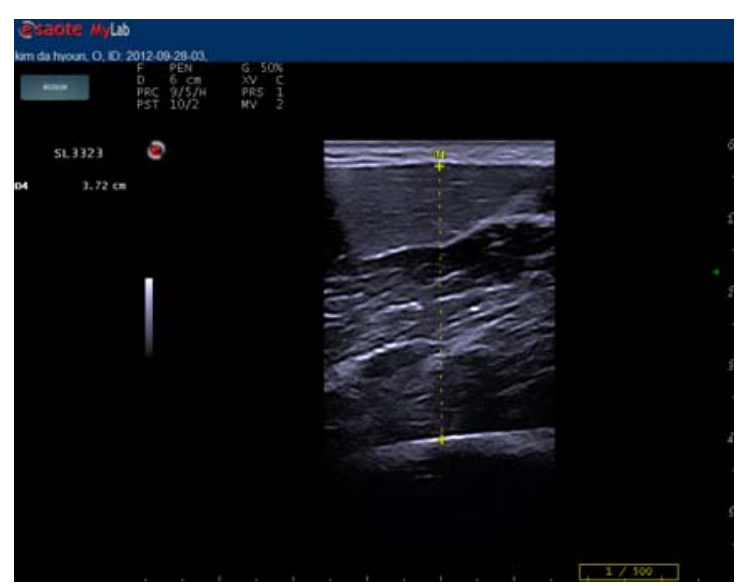

Fig. 4 Measurement of biceps brachii during rest-isometric contraction by ultrasound diagnosis (rest(sup), isometric contraction(low)

\section{IV. 고찰}

지연성 근육통이 발생하게 되면 급성염증반응과 통 증이 발생하게 된다 ${ }^{[13][14]}$. 한냉치료는 급성염증 반응 에 많이 사용되는 치료법으로 생리적 효과는 혈류를 감소시키고, 신경 전달 속도를 느리게 하고, 동통을 감 소시키며, 강직을 감소시키고, 초기 염증 반응을 감소 시키는 것으로, 근골격계 외상, 근경련, 동통, 초기 관 절염, 화상 등에 적용되고 있다 ${ }^{[15]}$. 따라서 본 연구는 선행논문에서 정상조직을 대상으로 하여 실제 한냉치 료를 받는 급성환자와 다르다는 제한점을 보완하기 위해 실제 급성염증과 비슷한 지연성 근육통을 유발 하여 연구를 시행 하였다.

지연성근육통에 대한 초음파진단기를 이용한 측정 도구로서의 가능성에 대해 지속적으로 연구되고 있다. 이완희(2012)의 연구에서 내측 비복근 지연성 근육통 유발후 초음파진단기로 측정한 내측 비복근의 우상각 을 비교함으로써 시간경과에 따른 변화 측정이 지연 성근육통을 감지하는 새로운 측정방법으로 사용될 수 있을 것이라 한것처럼 초음파진단기의 유용성이 다양 하게 연구되고 있다 ${ }^{[18]}$.근육의 기계적 성질 변화는 근 섬유의 길이(fascicle length), 우상각(pennation angle), 근 두께(muscle thickness)와 같은 근내부구조의 변화와 밀 접한 관련이 있다. 그중 근 두께는 힘을 발생시킬 수 록 더 커지게 된다. 하지만 근섬유조직에 생리학적 이
상이 있게되면 근수축시 두께 변화율이 작아지게 된 다 $^{[18][19]}$.

한냉치료 시 냉각기의 근육온도를 가장 잘 반영하 는 것이 한냉을 적용한 시간이라고 하였고, 사람의 심 부체온과 실외온도는 근육온도에 거의 영향을 주지 않는다고 하였다 ${ }^{[12]}$. 한냉의 방법은 선행논문에서 사용 된 방법으로 대기 중의 공기를 $-30{ }^{\circ} \mathrm{C}$ 로 냉각시키고, 압 축 냉각된 공기를 환부로 뿜어내는 장비(CRAis)를 사 용하였다. Belisky의 연구에서 습냉, 건냉, 냉동팩을 15 분간 적용하여도 피부 온도가 각각 $12^{\circ} \mathrm{C}, 9.9^{\circ} \mathrm{C}, 7.3^{\circ} \mathrm{C}$ 감소하는 데 그쳤지만, $\mathrm{CRAis}$ 는 피부의 온도 $20.9^{\circ} \mathrm{C}$ 를 낮추는 데 58 초의 시간이 소요된 것으로 보아, 이 장비 는 불과 수분 이내에 같은 효과를 볼 수 있어서 치료 시간 절약에 큰 도움을 주고 있다 ${ }^{[6]}$. 냉기를 둔근부에 5 분간 가하였을 때 피부는 냉기적용을 끝내는 시간에 가장 온도가 낮았고, 근육의 온도는 $2 \mathrm{~cm}, 4 \mathrm{~cm}, 6 \mathrm{~cm}$ 깊이 에서 냉기를 멈춘 후 각각 15 분, 20 분, 40 분에 가장 낮 아진다고 하였다. 피부 냉각 시 정맥혈관벽의 온도가 $23 \sim 28{ }^{\circ} \mathrm{C}$ 에서 통증이 나타나며, $7 \sim 10.5^{\circ} \mathrm{C}$ 에서 냉각통증 이 가장 심해지고 $20^{\circ} \mathrm{C}$ 의 식염수를 정맥에 주입하면 통증이 나타난다고 하였다 ${ }^{[17]}$.

적외선 치료는 원적외선과 근적외선으로 나뉘며 파 장에 따라 여러 가지 형태로 인체에 전달된다. 일반적 으로 피부표면에 열이 집중되며 표피 조직과 혈관 등 에 생리학적 영향을 미친다. 주로 통증 대사 물질의 변화에 영향을 미쳐 통증역치를 변화시켜줌으로써 임 상적으로 널리 사용되고 있다. 이러한 치료 원리를 이 용하여 본 연구에서 냉각통을 조절하기 위해 병용군 에 사용하였다. ${ }^{[7[8]}$. 본 연구에서는 피부온도 변화의 측정을 실온에서 $10^{\circ} \mathrm{C}$ 까지 일차 냉각 시키는데 소요되 는 시간, $10^{\circ} \mathrm{C}$ 에서 $20^{\circ} \mathrm{C}$ 로 일차자연가온 시키는데 소 요되는 시간, 다시 $10^{\circ} \mathrm{C}$ 까지 이차 냉각 시키는데 소요 되는 시간, $10^{\circ} \mathrm{C}$ 에서 $20^{\circ} \mathrm{C}$ 까지 이차자연가온 시키는데 소요되는 시간을 측정하였다. 실험에 사용한 냉기는 냉각 속도가 다른 한냉치료 도구들보다 빨라 냉각통 의 역치를 줄일 수 있었으며 치료시간의 단축 등을 나 타낼 수 있었다. 하지만 냉기 적용 중 지속적으로 발 생하는 냉각통을 없앨 수는 없기 때문에, 이러한 단점 을 보완하기 위해 적외선 광선 조사 치료기를 병행한 결과 통증유발 온도는 비슷하였지만 통증을 자각하는 
시점을 연장하여 냉기치료 시간을 연장 할 수 있었는 데 이는 적외선에서 발생하는 온열효과 때문이라 생 각된다. 본 연구에서 피부온도변화 측정 중 급격 한 온도의 하강으로 인해 냉기군 7명중 5 명 $(65 \%)$ 이 냉 각통증을 호소하였고 통증을 호소한 평균온도는 11. $7^{\circ} \mathrm{C}$ 였으며 평균시간은 41.5 초였다. 냉기와 적외선 병 용군에서는 7 명중 3 명 $(21 \%)$ 이 냉각통증을 호소하였고 통증을 호소한 평균온도는 $10.9^{\circ} \mathrm{C}$ 였으며, 평균시간은 52.6 초였다. 병용군이 냉기군에 비해 냉각통의 발생빈 도가 통계적으로 유의하게 적게 나타났으며 냉각통을 느끼는 시점까지의 소요시간도 유의하게 길어 냉기치 료 시간을 연장할 수 있는 효과가 있었다. 피부온도를 실온에서 $10^{\circ} \mathrm{C}$ 까지 낮추는 데 소요되는 시간은 1 차, 2 차 모두에서 냉기군이 짧은 시간이 소요되었다. 1 차 가온 되는 데 소요된 시간은 냉기와 적외선 병용군이 더 빨 리 가온되었다. 2 차 가온되는 데 소요된 시간은 냉기 와 적외선 병용군에서 더 늦게 가온되었다. 따라서 냉 기적용에 의해 피부온도가 $10^{\circ} \mathrm{C}$ 에 도달했다가 $20^{\circ} \mathrm{C}$ 로 재가온되는 시간이 2 차때 더욱 연장되었으므로, 이는 냉기치료의 효과를 높이기 위해서 일정한 간격을 두 고 2회 이상의 반복적인 냉기 적용이 피부온도의 재 상승시간을 늦춰주어 근육 내 온도를 낮추는데 더욱 효과적이라 생각되고, 결론적으로 냉기군보다 병용군 이 냉각통증을 낮추는데 더욱 효율성이 크다고 생각 된다.

\section{$\mathrm{V}$. 결론}

본 연구의 결과 냉기와 적외선 병용치료 시 냉기 단 독치료보다 냉각통증의 빈도가 낮게 나타났으며, 냉각 통증 자각 시점도 늦게 나타났다. 또한 충분한 냉기적 용 후 피부온도가 재가온되는데 있어서 냉기를 2회 적 용할 때가 1 회 적용할 때 보다 더 느려지며, 냉기 단독 치료보다 냉기와 적외선 광선 조사 병용치료 시 더 느 려짐을 나타내어 2회 이상의 반복적인 냉기 적용이 냉 기의 효용이 있다고 나타났다. 또한 초음파 영상을 통 한 상완이두근 두께 변화에 있어서 병용군이 대조군 보다 더 크게 나타나 이 효과를 뒷받침하게 되었다. 이러한 연구결과 자료는 향후 급성염증이 있는 환자 에게 한냉치료와 관련된 치료적인 자료로써 활용될
수 있을 것이라 생각되고 근골격계 초음파 진단기를 활용하여 통증에 대한 자각도를 간접적으로 표현하는 것이 구체화되어 임상에서 널리 활용될 것으로 보여 진다.

\section{참고문헌}

[1] Amundson H, "Thermotherapy and cryotherapy-effectson Joint degeneration in rheumatoid arthritis", Physiother Can, 1979.

[2] 김종만, 박상성, 김원호, 신헌석, 김연중, “유지-이완기법과 냉치료가 지연성 근육통에 미치는 효과”, 2000.

[3] 양두창, 이규훈, 이상건, 박시복, "냉기치료 때에 나타나는 냉각통에 대한 적외선효과”, 대한재활의학회지, 2003.

[4] Black CD, Dobson RM., ".Prior Eccentric Exercise Augments Muscle Pain and Perception of Effort During Cycling Exercise", Clin J Pain, 2013.

[5] Jeong HJ, ".Effects of a Short Course of Oral Prednisolone in Patients with Bladder Pain Syndrome with Fluctuating, Worsening Pain despite Low-Dose Triple Therapy, Int Neurourol J, 2012.

[6] Belisky RB, Odam SJ, Hubley-Kozey C, "Evaluation of the effectiveness of wet ice, dry ice, and cryogenic packs in reduceing skin temperature", Phys Ther 67: 1080-1084, 1987.

[7] Borken N, Bierman W, "Temperature changes produced by spraying with ethyl chloride", Arch Phys Med Rehabil, 1955.

[8] Lehmann JF, DeLateur BJ, "Cryotherapy". In: Lehmann FJ, editor. Therapeutic heat and cold 4th ed., Williams \& Wilkins, 1989.

[9] Borken N, Bierman W, "Temperature changes produced by spraying with ethyl chloride", Arch Phys Med Rehabil 1955.

[10] 이정권, 김미정, 박시복, 김영호, "슬관절통 환자에서 초저온 냉기를 이용한 한냉치료후 시각적 상사 척도값의 변화, 1999.

[11] 한승진, 이규훈, 이상건, 박시복, "둔부에서 냉기와 적외선병용 치료시 둔부의 피부 온도의 변화", 대한 재활의학회지, 2003.

[12] Jamurtas AZ, Theocharis V, Tofas T, Tsiokanos A, Yfanti C, Paschalis V, Koutedakis Y, and Nosaka K, "Comparison between leg and arm eccentric exercise of the same relative intensity on indices of muscle damage". Eur J Appl Physiol, 2005.

[13] Prawit Janwantanaku, "Cold and heat application in musculoskeletal injury", Physiotherapy, 2006. 
[14] Prawit Janwantanaku, "Cold pack skin interface temperature during ice treatment with various levels of compression", Physiotherapy, 2009.

[15] Basagoitia F, Bolanos OR, Morse DR, Furst M, "The effect of hot and cold external application on experimentally induced inflamma- tory edema in guinen pigs: A pilot study", Ann Dent, 1985.

[16] Fruhstorfer H, Lindblom U, "Vascular participation in deep cold pain”, Pain, 1983.

[17] Jutte LS, Merrick MA, Ingersoll CD, Edwards JE, "The relationship between intramuscular temperature, skin temperature, and adipose thickness rewarming", Arch Phys Med Rehabil 2001.

[18] 이완희, 조기훈, 이경숙, 김미화, “시간경과에 따른 연성근통증 내측 비복근의 초음파 영상., 한국학기술학회논문지 13, 2012.

[19] Fukunaga T, Kawakami Y, Kuno S, Funato K,, Fukashiro S. "Muscle architecture and function in humans", Journal of Biomechanics, Vol. 30 No. 5, 1997. 